\title{
ALTERNARIA-, FUSARIUM- JA VENTURIA-ITIODEN RUNSAUS ILMASSA
}

\author{
J. E. HÅrdh ja M. SUlkinoja \\ Puutarhantutkimuslaitos, Piikkiö
}

Saapunut 12. 10. 1957.

Monien kasvitauteja aiheuttavien sienien itiöt leviävät ilmavirtojen mukana paikasta toiseen. Siksi saattaa tuulen mukana leviävien sienien esiintyminen ratkaisevasti olla riippuvainen niiden itiöiden runsaudesta ilmassa. Itiöitä voi olla sekä lähellä maanpintaa että varsin korkeallakin ilmassa riippuen tuulen suunnasta ja nopeudesta, onpa ruostesienien itiöitä tavattu GäUmansin (4) esittämien tietojen mukaan jopa 5000:n m:n korkeudessa sekä 1800 :n km:n päässä lähtökohdastaan. Vaikka itiöt saattavat kulkeutua pitkiäkin matkoja, vähenee niiden määrä ilman tilavuusyksikköä kohden (tiheys) sekä niiden aiheuttaman saastunnan mahdollisuus, kun etäisyys itiöiden lähtökohdasta kasvaa. Tämä johtuu, kuten mm. BUCHANAN ja KimmeY (1) ovat osoittaneet, siitä, että itiöiden hajonta lähempänä kuin 10:n metrin etäisyydessä saastunnanlähteestä on suuri. Etäisyyden siitä kasvaessa pysyy itiötiheys samojen tutkijoiden mukaan lähes muuttumattomana. Sanotun perusteella voidaan $\mathrm{mm}$. ruostesienien leviämistä seurata määrittämällä saastunnan lähtökohta sekä se matka, jonka itiöt ovat kulkeutuneet. Myös muiden kasvitautien esiintymisestä voidaan tehdä arvioita määrittämällä itiörunsaus saastunnalle altista kasvustoa lähinnä olevassa ilmassa. Tällaisesta saattaa olla hyötyä joidenkin kasvitautien, esim. omenaruven ja perunaruton torjuntaa järjestettäessä.

Omenarupea aiheuttavan Venturia inaequalis (Cooke) Wint. -sienen koteloitiöitä, jotka touko- ja kesäkuun aikana aiheuttavat maassamme omenaruven alkusaastunnan, sinkoutuu ilmaan tavallisimmin useista eri tahoilla olevista hedelmätarhoista. Siitä syystä on rupisaastunnan mahdollisuus olemassa sellaisissakin hedelmätarhoissa, joissa tauti on aikaisempina vuosina saatu torjutuksi. Lisäksi on ilmeistä, että tuulella, ilman kosteudella sekä sateilla on huomattava vaikutus ilman rupi-itiöiden runsauteen ja saastunnan mahdollisuuteen. Omenarupi-itiöiden sinkoutumista tarkkaillaan maassamme useilla hedelmänviljelyseuduilla tutkimalla, milloin talvehtineissa omenanlehdissä kehittyneet itiöt kypsyvät. Tämä tapahtuu aikaisemmin (7) selostettuja nk. i t i ö n p y y d y k s i ä käyttäen. Siten voidaan yksittäisissä puutarhoissa todeta talvehtineista lehdistä sinkoutuvien itiöiden määrä, mutta ei niiden runsautta ilmassa. Omenaruven leviämisen sekä taudin torjunnan kannalta on kuitenkin tärkeä tietää, miten runsaasti ja miten kauan 


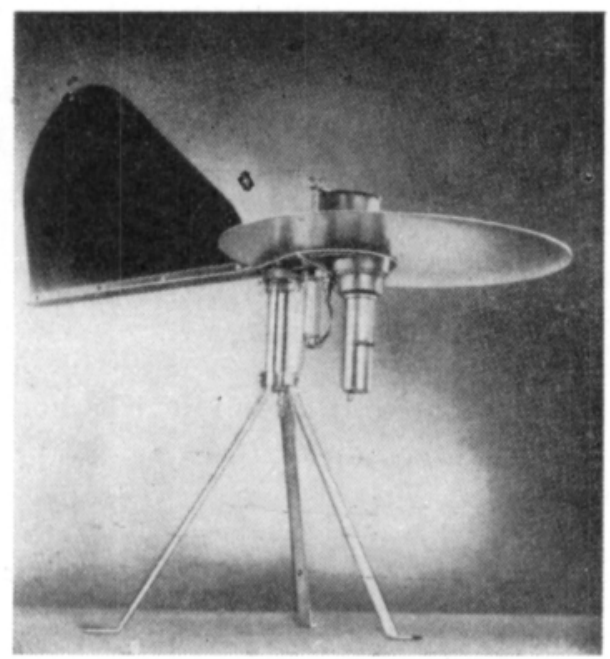

Kuva 1. Hirst spore trap-laite.

Fig. 1. Hirst spore trap.

rupi-itiöitä leijailee ilmassa kulloinkin sateen aikana ja sen jälkeen. Tämän selvittämiseksi tutkittiin Puutarhantutkimuslaitoksen hedelmätarhassa vuosina 1956 ja 1957 itiöiden runsautta ilmassa toukokuun puolivälistä heinäkuun alkuun saakka, jolloin omenaruven koteloitiötä sinkoutuu talvehtineista lehdistä. Samalla tutkittiin ilmassa olevien Alternaria- ja Fusarium-kuromien runsautta.

\section{Menetelmät}

Tutkimukset suoritettiin Hinstin (5) suunnittelemaa nk. Hirst spore t r a p-laitetta käyttäen. Sen sähköllä käyvä pumppu imee ilmaa 10 litran nopeudella minuutissa kapean tuloaukon kautta, jonka takana, ilmatiiviissä kotelossa, on vaseliinilla sivelty objektilasi. Aukko on $2 \times 14 \mathrm{~mm}$ ja sen sisäreunan etäisyys objektilasista $0.6 \mathrm{~mm}$. Objektilasi on pystyasennossa telineeseen kiinnitettynä, joka kellolaitteen vetämänä siirtyy ylöspäin $2: n$ mm:n matkan tunnissa. Koko laite on pystysuoran akselin varassa ja asettuu peräsinlevyn vaikutuksesta aina siten, että tuloaukko on tuulta vasten suunnattuna (kuva 1). Tuloaukkoa suojaa sateelta sen yläpuolella oleva pyöreä suojuslevy. Laite on kolmijalan varassa siten, että tuloaukko on 1.5:n metrin korkeudella maanpinnasta.

Spore trap-laite oli kumpanakin vuonna toiminnassa 8:n viikon ajan, 24 tuntia vuorokaudessa. Objektilasi vaihdettiin kerran vuorokaudessa, v. 1956 kunakin päivänä klo 8.00 ja v. 1957 klo 14.00. Siten objektilasilla, joka oli ollut vuorokauden ajan laitteessa, oli 50:n mm:n pituinen ja 14:n mm:n levyinen juova, johon kaikki ilmassa leijailevat ja ilmavirran mukana sisään tulleet hiukkaset olivat tarttuneet. Objektilasien mikroskooppista tutkimista varten laseja lämmitettiin varovasti $35^{\circ} \mathrm{C}$ :ssa, jolloin lasilla olevat hiukkaset kiinnittyivät vaseliiniin. Jäähtyneelle objektilasille asetettiin sen jälkeen peitinlasi, johon oli sivelty runsaasti kiinnitys- 
ainetta. Kiinnitysaineena käytettiin Spore trap-laitteen mukana seuraavaa ohjekirjaa noudattaen seosta, jossa oli 50 osaa "Solvarwin $20 \%$ :sta vesiliuosta, 25 osaa maitohappoa ja 25 osaa fenolin $6 \%$ :sta vesiliuosta. "Solvar" on hydrolysoitua polyvinylasetaattia sisältävä, mikroskooppiseen työskentelyyn tarkoitettu kiinnitysaine.

Kun Spore trap-laitteen tuloaukko on $2 \mathrm{~mm}$ leveä ja kun objektilasi siirtyy pituussuunnassa 2:n mm:n verran tunnissa, on jokainen objektilasiin poikittain piirretty viiva 1 tunnin ajan aukon kohdalla ilmavirrassa. Objektilasia kohtaavan ilman määrä on $2.06 \mathrm{~m}^{3}$ lasipinnan $\mathrm{cm}^{2}$ :ä kohden. Itiöiden laskemista varten valittiin objektilasin pituussuunnassa olevan keskiviivan kohdalla mikroskoopin näkökentät 4:n mm:n päästä toisistaan (objektiivi $10 \times$ ). Näkökentän suuruus oli tällöin $0.95 \mathrm{~mm}^{2}$, joten 10 itiötä näkökentässä vastasi 487 :ää itiötä $\mathrm{m}^{3}$ :ssä ilmaa.

Laite sijoitettiin kumpanakin vuonna itäkaakkoon loivasti viettävälle rinteelle, jonka länsireunassa on korkea metsäinen harju. Laitteen eteläpuolella, n. 30:n metrin päässä siitä, oli 7:n metrin korkuinen kuusiaita ja pohjoiseen sekä itään päin olevalla aukealla n. 1000 omenapuuta käsittävä hedelmätarha. Joka puolella laitteen välittömässä läheisyydessä oli omenapuita sekä maassa osittaisesta tuulensuojasta johtuen runsaasti edellisen vuoden omenanlehtiä.

Samalla kun ilman itiörunsautta tutkittiin edellä selostetulla tavalla, tarkattiin rupi-itiöiden sinkoutumista talvehtineista omenanlehdistä. Tämä tapahtui aikaisemmin mainittua itiönpyydystä käyttäen.

\section{Venturia ina equalis-itiöt}

Rupisienen koteloitiöiden runsautta ilmassa on eri maissa jo kauan selvitetty. Yhdysvalloissa tutkivat tätä FreY ja KeItT (2) sekä KeItT ja Jones $(8,9)$ käyttämällä imupumppuna pölynimuria, johon oli kiinnitetty kaasumittari, sekä nitroselluloosasuodatinta ja totesivat vuorokauden aikana ilman itiöpitoisuudessa suuria vaihteluja. Suurin määrä rupi-itiöitä, minkä FREY ja KEITT (1.c.) totesivat, oli 2500 itiötä $\mathrm{m}^{3}$ :ä kohden. Sveitsissä tutki WiesmanN (12) rupi-itiöiden runsautta ripustamalla vaseliinilla voideltuja objektilaseja omenapuiden oksiin, mutta näin saatiin vain suhteellisia arvoja itiörunsaudesta. Käyttämällä sen sijaan imupumppua sekä nitroselluloosasta tehtyä suodatinta määritti WiesmanN (13) myöhemmin itiöiden runsauden ilman tilavuusyksikköä kohden. Hän totesi, että itiöiden määrään vaikuttaa ennen kaikkea sateen määrä kunakin päivänä. Kuta enemmän satoi sitä runsaammin oli itiöitä ilmassa. Kaste sen sijaan ei riittänyt aiheuttamaan itiöiden sinkoutumista. Suurin Sveitsissä mitattu rupi-itiömäärä oli v. 19327200 itiötä $/ \mathrm{m}^{3}$. Seuraavana vuonna oli maksimi samassa tarhassa vain 1370 itiötä $/ \mathrm{m}^{3}$, mikä Wiesmansin (13) mukaan johtui siitä, että maa hedelmätarhassa oli edellisenä syksynä kynnetty.

SCHNEIDERHAN ja Fromme (11) huomasivat ilman itiöpitoisuuden lisääntyvän 10:n minuutin kuluttua sateen alkamisesta. Suurin itiöiden määrä saavutettiin Holzin (6) suorittamissa kokeissa 30:n minuutin kuluttua sateen alusta lukien. 


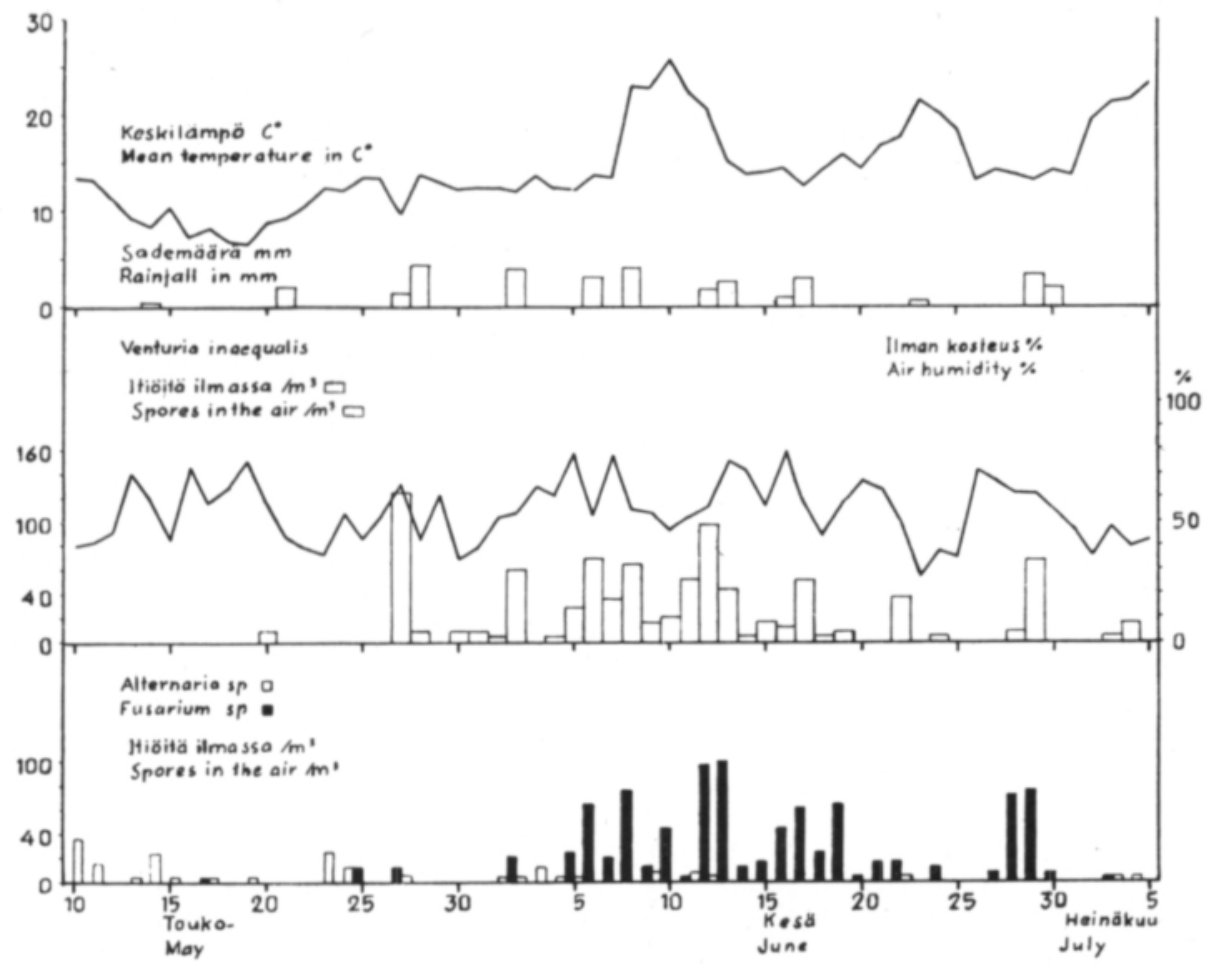

Kuva 2. Vuorokauden keskilämpötila, sademäärä, ilman suhteellinen kosteus sekä sieni-itiöiden runsaus keskimäärin vuorokaudessa Piikkiössä v. 1956.

Fig. 2. Daily mean temperature, amount of rain, relative air humidity and mean daily No. of spores at Piikkiö in 1956.

K o k e e t Piik kiössä. V. 1956 oli Spore trap-laite toiminnassa toukokuun 10:nnestä heinäkuun 5:nteen päivään (kuva 2). Tänä aikana oli 10. 6. saakka kolea kausi, jonka jälkeen seurasi 5:n päivän pituinen lämmnin jakso. Myös kesäkuun 20-25. päivinä oli vuorokauden keskilämpö huomattavan korkea Sanottuna aikana oli 14 sadepäivää, ja vuorokauden sademäärä kunakin sadepäivänä alle $5 \mathrm{~mm}$. T a lve h t in e is s a o m en a n le h d is s ä havaittiin ensimmäiset rupi-itiöt 13. 5. ja suurin yhden vuorokauden aikana singonnut määrä 27. 5. I 1m a s s a todettiin ensimmäiset itiöt 20. 5. Itiöiden lukumäärä oli suurimmillaan 27. 5. klo 10, jolloin niitä laskettiin olevan $344 \mathrm{kpl} / \mathrm{m}^{3}$. Koko vuorokauden keskimääräinen itiöpitoisuus sanottuna päivänä oli $130 \mathrm{kpl} / \mathrm{m}^{3}$. Tämän jälkeen sinkoutui lehdistä itiöitä ainoastaan sadepäivinä 1. 6., 5. 6., 7. 6., 13. 6., 15. 6. ja 22. 6. Ilmassa oli itiöitä yhtämittaa 27. 5.-19. 6. välisen ajan sekä vielä 22. 6., 24. 6., 28-29. 6. ja 3-4. 7. (kuva 2). Tämä osoittaa, että itiöntarkkailu, jota suoritetaan vain muutamien paikalta kerättyjen lehtien perusteella, ei aina anna täysin tarkkaa kuvaa itiöiden esiintymisestä hedelmätarhan ilmassa. Myös primäärisen saastuntakauden alkamista ja loppumista koskevat päätelmät saattavat siten tehtyinä olla virheellisiä ja poiketa jopa 10:n päivän verran niistä ajankohdista, jolloin itiöitä on ilmassa. 


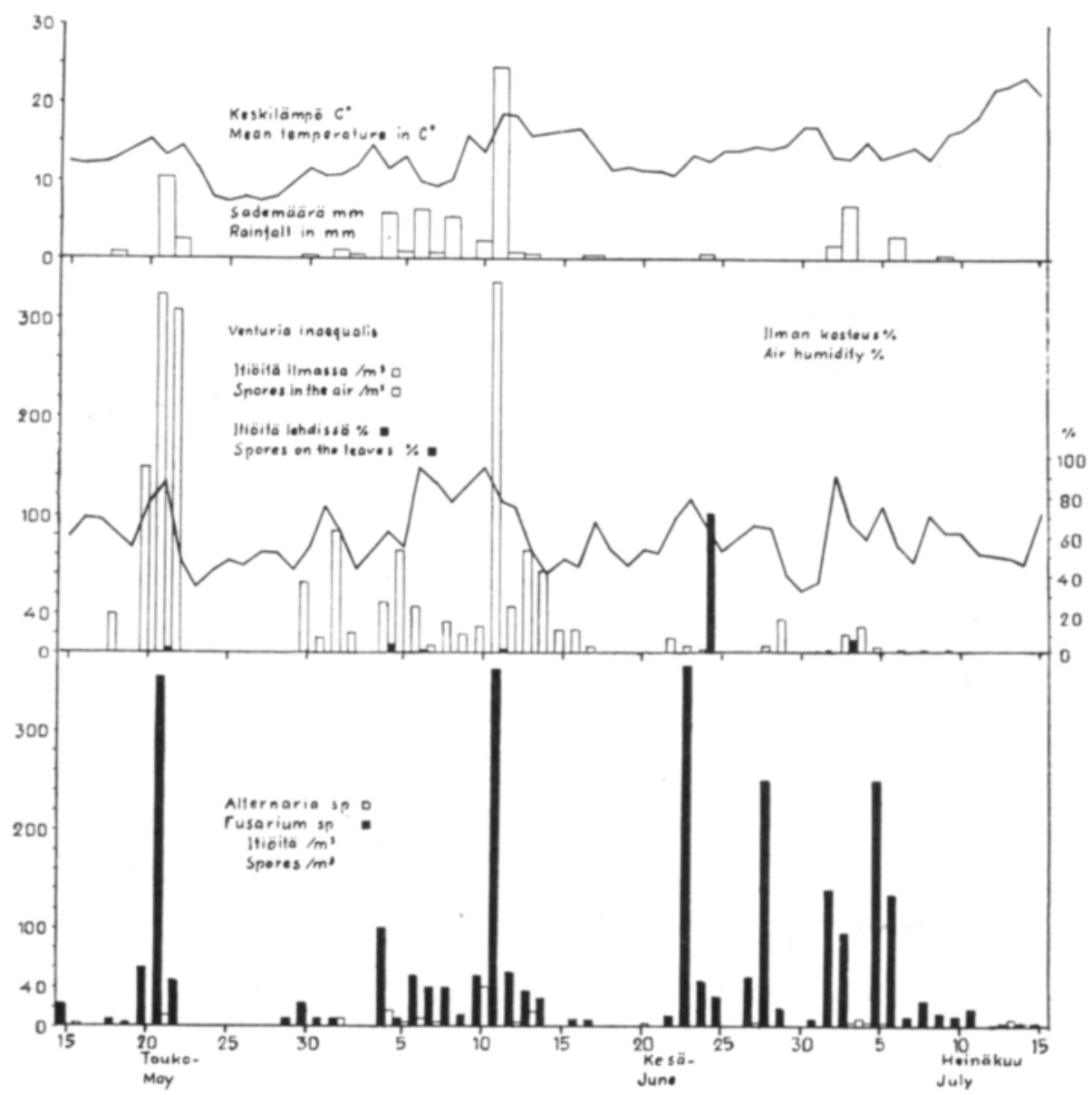

Kuva 3. Vuorokauden keskilämpötila, sademäärä, ilman suhteellinen kosteus, ilmassa olevien sekä lehdistä sinkoutuneiden Venturia inaequalis-itiöiden määrä sekä Alternaria ja Fusarium-itiöiden runsaus ilmassa (keskimäärin vuorokaudessa) Piikkiössä v. 1957.

Fig. 3. Daily mean temperature, amount of rain, relative air humidity, No. of Ve $n$ t u $r$ i a in a $q$ q a $\mathrm{l}$ is spores in the air and discharged from the leaves, No. of Alternaria and $F$ u $\operatorname{lor} i$ u spores at Piikkiö (daily means) in 1957.

Myös v. 1957 poikkesivat talvehtineista lehdistä tehdyt havainnot ilman itiöpitoisuutta koskevista havainnoista. Spore trap-laite oli toiminnassa 15. 5.-15. 7. välisen ajan (kuva 3). Sadepäiviä oli sanottuna aikana 21, ja vuorokauden sademäärä 6:na päivänä yli $5 \mathrm{~mm}$. Kahtena päivänä satoi erittäin runsaasti, $21.5 .10 .5 \mathrm{~mm}$ ja 11.6. $24.4 \mathrm{~mm}$. Ensimmäiset itiöt sinkoutuivat $\mathrm{leh} \mathrm{dist} \mathrm{ä} \mathrm{18.} \mathrm{5.} \mathrm{ja} \mathrm{viimeiset}$ 16. 7. Runsaimmin niitä sinkoutui 24 . 6., jolloin $71.4 \%$ kaikista sanotuissa lehdissä olevista itiöistä irtaantui. I $1 \mathrm{~m}$ a s s a oli Spore trap-laitteella tehtyjen tutkimusten mukaan itiöitä ensimmäisen kerran 18. 5., runsaimmin 21-22. 5. ja 11. 6. sekä viimeisen kerran 6. 7. Lehdissä todettiin nyt, kuten edellisenäkin vuonna, itiöitä vain sadepäivinä kun niitä ilmassa oli kaikkina sadepäivinä sekä lisäksi sateita seuraavina, täysin sateettomina päivinä. Niinpä aikana 30. 5.-17. 6. oli itiöitä ilmassa 


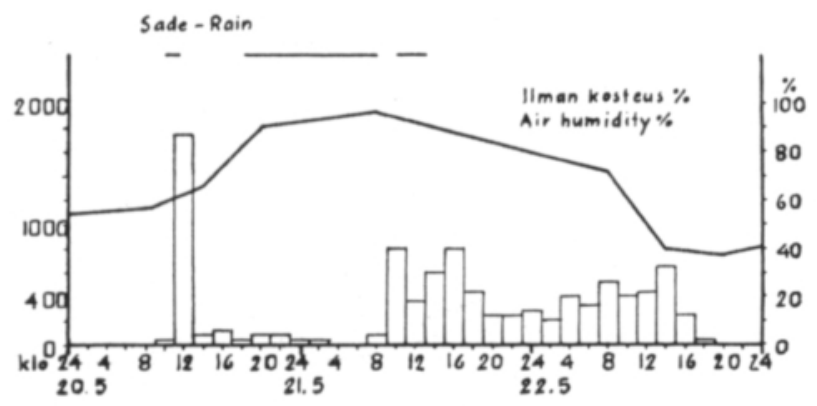

Kuva 4. Sateet sekä rupi-itiöiden runsaus Piikkiössä 20-22. 5. 1957.

Fig. 4. The rain periods and Nos. of apple scab spores at Piikkiö from 20th to 22d May, 1957

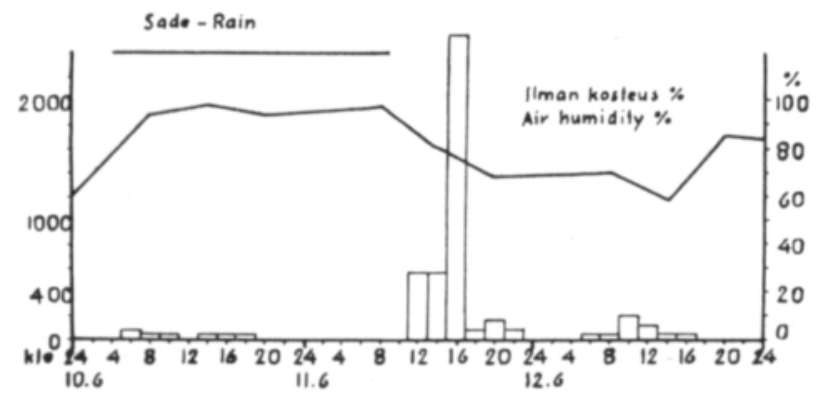

Kuva 5. Sateet sekä rupi-itiöiden runsaus Piikkiössä 10-12. 6. 1957.

Fig. 5. The rain periods and Nos. of apple scab spores at Piikkiö from 10th to 12th June, 1957.

kaikkina muina päivinä paitsi 3. 6. kun sadepäiviä tänä aikana olivat vain 30. 5.2. 6., 4-8. 6., 10-12. 6. ja 17. 6. Myös saastunta-ajan lopussa esiintyi tässä suhteessa poikkeamaa siten, että itiöitä sinkoutui tutkituista lehdistä vielä 6. 7.:n jälkeen, jolloin niitä ilmassa ei enää todettu. Tämä voi johtua siitä, että saastuntakauden lopulla sinkoutuu lehdistä vain yksittäisiä itiöitä ja että itiöitä tällöin on ilmassa niin vähän, ettei niitä Spore trap-laitteella voida todeta.

Sen seikan yksityiskohtaista tarkastelua varten, miten kauan itiöitä esiintyy ilmassa sateen tauottua, esitetään piirrokset kahdesta ajanjaksosta v. 1957, jolloin itiöitä oli runsaasti. Toukokuun 20 p. alkoi sade klo 10 ja päättyi klo 11.30 alkaakseen uudestaan klo 19.00. Sade jatkui seuraavaan aamuun klo 8:aan saakka, ja sadetta oli vielä 21. 5. klo 10-13 (kuva 4). Itiöitä todettiin ilmassa 20.5. jo klo 10, eli samaan aikaan kuin sade alkoi. Eniten niitä oli 2:n tunnin kuluttua sateen alkamisesta, jolloin Spore trap-laite osoitti niitä olevan $1768 \mathrm{kpl} / \mathrm{m}^{3}$. Koko yön kestäneen sateen aikana oli itiöitä vain vähän, $50-150 \mathrm{kpl} / \mathrm{m}^{3}$. Toukokuun 21. p, jolloin sade päättyi klo 13 sekä sitä seuraavana sateettomana päivänä oli itiöitä klo 18:aan saakka $400-900 \mathrm{kpl} / \mathrm{m}^{3}$. Sama seikka ilmenee kuvan 5 osoittamassa tapauksessa, jossa sadetta kesti yhtämittaa 10. 6. klo 4:stä 11.6. klo 9:ään. 10. 6. oli itiöitä sateen aikana vain vähän leijailemassa, enintään $50 \mathrm{kpl} / \mathrm{m}^{3}$, kun niiden määrä sateen jälkeen, 11. 6. klo 16 saavutti kesän maksimin, 2850 itiötä/ $/ \mathrm{m}^{3}$. Tämän jälkeen esiintyi itiöitä vähäisessä määrin vielä 32 tunnin kuluttua sateen päättymisestä, eli 
12. 6. klo 16:een saakka. On syytä mainita, että kesäkuun 11. päivänä oli sademäärä Piikkiössä poikkeuksellisen runsas, $24.4 \mathrm{~mm}$. Runsas sade saattaa tämän mukaan sirroittaa" lehdistä enemmän itiöitä kuin yhtä kauan kestävä heikko sade, jollaista myös WiEsmann (12) totesi tutkimuksissaan, kuten mainittu. Lämpötilalla ja ilman suhteellisella kosteudella sen sijaan ei näytä olevan vaikutusta rupi-itiöiden määrään ilmassa.

Mainituista esimerkeistä (kuvat 4 ja 5) käy lisäksi ilmi, että omenaruven itiöitä on ilmassa runsaimmin päivänvalon aikana klo 8:sta klo 22:een. Mainittakoon, että GREGoRY (3) luokittelee eri sienisuvut joko "päiväitiöryhmään" tai "yöitiöryhmään» kuuluviksi sen perusteella, leviääkö niiden itiöitä runsaammin päivällä vai yöllä. Alternaria, Curvularia ja Penicillium osoittautuivat PANzerin ym. (10) tutkimuksissa edelliseen, Cladosporium, Leptosphaeria ja Ophiobolus jälkimmäiseen ryhmään kuuluviksi. Venturia inaequalis on nyt selostettujen kokeiden mukaan sienilaji, jonka itiöitä sinkoutuu ilmaan runsaimmin päivän aikana.

\section{A lternaria- ja Fusarium-itiöt}

Vähäsateisena alkukesänä vuonna 1956 oli Alternaria sp.:n kuromaitiöitä ilmassa runsaimmin toukokuun $10-15$. päivinä. Tänä aikana oli vain yksi sadepäivä (14.5.) ja sateen määrä silloin $0.3 \mathrm{~mm}$. Itiöitä oli eniten 10. 5., jolloin niitä klo 18 laskettiin olevan $340 \mathrm{kpl} / \mathrm{m}^{3}$ (kuva 2). Vuorokaudessa oli itiöitä keskimäärin $37 \mathrm{kpl} / \mathrm{m}^{3}$. Sanottuna vuonna todettiin Alternaria-itiöitä koko havaintokauden ajan heinäkuun 5. päivään saakka, mutta niiden määrä oli kesä- ja heinäkuussa varsin vähäinen. Vuonna 1957, jolloin alkukesä oli runsassateinen ja jolloin sateen määrä oli suurin 11. 6., todettiin Alternaria-itiöitä runsaimmin sanottuna päivänä (kuva 3). Niitä oli silloin klo 10:n aikaan $246 \mathrm{kpl} / \mathrm{m}^{3}$ ja keskimäärin koko vuorokauden aikana $41 \mathrm{kpl} / \mathrm{m}^{3}$. Alternaria-itiöitä saattaa näiden havaintojen mukaan esiintyä sateen aikana tavallista runsaammin, mutta myös sateettomina päivinä niitä leijailee ilmassa.

Fusarium sp.:n kuromaitiöitä todettiin v. 1956 ensimmäisen kerran 17. 5. Runsaimmin niitä oli kesäkuun 5. päivän jälkeen, jolloin Piikkiössä alkoi lämmin kausi ja jolloin vuorokauden keskilämpötila kohosi huomattavasti. V. 1957 oli Fusarium-itiöitä eniten 21. 5., 11. 6. ja 23. 6., jolloin satoi runsaasti ja jolloin lämpötila oli korkea. Itiöitä laskettiin olevan 21. 5. klo 141980,11 . 6. klo 121520 ja 23. 6. klo $121820 \mathrm{kpl} / \mathrm{m}^{3}$. Vuorokauden keskimääräinen itiöpitoisuus sanottuina päivinä oli $341-368 \mathrm{kpl} / \mathrm{m}^{3}$. Fusarium-itiöiden määrä ilmassa on näiden kokeiden mukaan suurimmillaan runsaiden sateiden aikana, jos lämpötila samalla on korkea. Lämpötila näyttääkin varsin huomattavasti vaikuttavan Fusarium-lajien itiörunsauteen ilmassa kun taas Alternaria- ja Venturia-itiöiden esiintyminen ei ainakaan samassa määrin ole lämpötilasta riippuvaa.

Edellä on osoitettu, että omenaruven itiöitä on primäärisen saastuntakauden aikana kaikkina sadepäivinä ilmassa. Lisäksi voi ilman rupi-itiöiden määrä olla huomattavan korkea runsaita sateita seuraavina, sateettomina päivinäkin, vaikka 
itiöitä sinkoutuu talvehtineissa lehdissä olevista kotelopulloista vain sateella. Spore trap -laitteella tutkituissa itiönäytteissä niitä todettiin vielä 3:ntena päivänä sateen päättymisestä. Tähän voivat useat syyt olla vaikuttamassa. Itiöitä saattaa kulkeutua tuulen mukana muilta seuduilta, joilla sääsuhteet ovat toisenlaiset kuin tarkasteltavana olevassa hedelmätarhassa. Edelleen voi osa omenanlehtiä olla varjossa ruohon sisässä tai ojissa ja siten pysyä kauan märkinä, jolloin niistä sinkoutuu jatkuvasti itiöitä.

Mainituista syistä johtunee myös, että rupi-itiöiden enimmäismäärät ilmassa ja talvehtineissa lehdissä eivät aina satu samoihin päiviin, kuten tapahtui selostetuissa kokeissa v. 1957.

Tärkein merkitys nk. itiöntarkkailulla, jota hedelmänviljelyalueillamme suoritetaan omenaruven torjunnan ajankohtien määrittämiseksi, on primäärisen saastunta-ajan alun ja lopun toteamisessa. Itiöntarkkailu, jota suoritetaan yksittäisten, hedelmätarhasta kerättyjen talvehtineitten omenanlehtien perusteella, saattaa selostettujen kokeiden mukaan antaa epätarkkoja tuloksia siitä, milloin rupi-itiöitä on ilmassa ensimmäisen sekä viimeisen kerran. Tällä seikalla on ilmeisesti kuitenkin vain vähäistä merkitystä omenaruven torjunnan kannalta, sillä saastunta-ajan alussa ja lopussa sinkoutuvien itiöiden määrä on varsin pieni (vrt. kuvat 2 ja 3 ). Edelleen sellaiset itiöt, jotka kulkeutuvat sateettomina päivinä muualta, eivät voi aiheuttaa rupisaastuntaa, koska omenapuiden lehdet silloin ovat kuivia ja koska rupisaastunnan edellytyksenä on, että omenapuiden lehdet ovat määrätyn pituisen ajan märkinä, kuten aikaisemmin on selostettu (7). Myös tähänastiset tulokset ruventorjunnassa (7) viittaavat siihen, että suorittamalla itiöntarkkailua talvehtineiden omenanlehtien perusteella saadaan torjuntaa varten riittävän tarkkoja tietoja saastunta-ajan alkamisesta sekä päättymisestä ja että järjestämällä ruiskutukset näiden havaintojen mukaan omenarupi saadaan tyydyttävästi torjutuksi.

Alternaria-itiöitä oli hedelmätarhassa sekä sadepäivinä että sellaisina päivinä, jolloin ei sadetta ollut. Näiden itiöiden runsauteen ei sääsuhteiden vaikutusta voitu nyt selostetuissa tutkimuksissa todeta. Sen sijaan Fusarium-itiöitä on ilmassa eniten sateisina ja lämpiminä päivinä, eikä vuorokauden eri aikoina näyttänyt olevan eroa näiden runsaudessa. Tuulen suuntaa ja voimakkuutta sekä sen vaikutusta itiönrunsauteen ei näissä kokeissa selvitetty.

\section{Yhteenveto}

Hirst spore trap-laitteella todettiin Venturia inaequalis-itiöiden määrä ilmassa sitä suuremmaksi kuta runsaammin satoi. Suurin laskettu itiömäärä oli v. 1956 $344 \mathrm{kpl} / \mathrm{m}^{3}$ ja v. $19572850 \mathrm{kpl} / \mathrm{m}^{3}$.

Itiöitä esiintyi ilmassa heti sateen alettua ja niitä oli siinä vielä $3: n$ vuorokauden kuluttua sateen päättymisestä.

Talvehtineitten omenanlehtien perusteella suoritetut havainnot siitä, milloin rupi-itiöitä on ensimmäisen ja viimeisen kerran kesän aikana hedelmätarhassa, saattavat poiketa ilmassa olevia rupi-itiöitä koskevista havainnoista. Omenaruven 
torjuntamenetelmiin tämä seikka ei ilmeisesti kuitenkaan vaikuta, koska saastuntakauden alussa ja lopussa sinkoutuvien itiöiden määrä on pieni.

Alternaria-itiöitä esiintyy ilmassa sekä sadepäivinä että sateettomina, eivätkä säätekijät näytä vaikuttavan ilman itiörunsauteen. Fusarium-itiöitä on ilmassa eniten lämpiminä sadepäivinä, ja korkea lämpötila näyttää edistävän Fusariumitiöiden leviämistä. Suurin Alternaria-itiöiden määrä oli $340 \mathrm{kpl} / \mathrm{m}^{3}$ ja Fusariumitiöiden $1980 \mathrm{kpl} / \mathrm{m}^{3}$.

\section{K I R J A L L I S U U S}

(1) Buchanan, T. S. \& Kimmey, J. W. 1938. Initial tests of the distance of spread to and intensity of infection on Pinus monticola by Cronartium ribicola from Ribes lacustre and R. viscosissimum. J. agric. Res. 56: 9-30.

(2) FreY, C. N. \& KeItT, G. W. 1925. Studies of spore dissemination of Venturia inaequalis. Ibid. 30: $529-540$.

(3) Gregory, P. H. 1952. Spore content of the atmosphere near the ground. Nature 170: 475-477,

(4) GäUmann, E. 1951. Pflanzliche Infektionslehre. $681 \mathrm{~S}$. Basel.

(5) Hirst, J. M. 1952. An automatic volumetric spore trap. Ann. appl. Biol. 39: 257-265.

(6) HoLz, W. 1939. Der Einfluss der März-Temperaturen auf die Geschwindigkeit des Reifungsvorganges von Venturia inaequalis-Peritezien. Angewandte Botanik 21: 209-214.

(7) HẢrdh, J. E. 1955. Omenarupi ja sen torjunta Suomessa. Valt. maatal. koetoim. julk. 144: 1-43.

(8) KeItr, G. W. \& Jones, L. K. 1925. Frequencies of ascospores of Venturia inaequalis in orchard air. Phytopathology 15: 57.

(9) —— \& Jones, L. K. 1926. Studies of the epidemiology and control of apple scab. Wisconsin Agr. Exp. Sta. Res. Bull. 73: 1-104.

(10) Panzer, J. D., Tullis, E. C. \& VAn Arsdel, E. P. 1957. A simple 24-hour slide spore collector. Phytopathology 47: 512-514.

(11) Schneiderhan, F. J. \& Fromme, F. D. 1924. Apple scab and its control in Virginia. Va. Agric. Exp. Sta. Bull. 236: 1-29.

(12) WiesmanN, R. 1932. Untersuchungen über die Ueberwinterung des Apfelschorfpilzes Fusicladium dendriticum (Wallr.) Fckl. im toten Blatt sowie die Ausbreitung der Sommersporen (Konidien) des Apfelschorfpilzes. Landw. Jbuch der Schweiz 46: 619 - 679.

1935. Untersuchungen über die Bedeutung der Ascosporen (Wintersporen) und der Konidien an den schorfigen Trieben für die Entstehung der Primärinfektionen des Apfelschorfpilzes Fusicladium dendriticum. Ibid. 49: 147-175.

S U M M A R Y :

THE CONTENT OF ALTERNARIA, FUSARIUM AND VENTURIA SPORES IN THE AIR

J. E. Hárdh \& M. Sulkinoja

Horticulture Research Institute, Piikkiö

The spore content of orchard air was determined in 1956-1957 at the Horticulture Research Institute by means of a Hirst spore trap (5). The spore countings were performed according to the Instruction leaflet given by the manufacturer of the spore trap. 
In 1956 the spore trap was in action from the 10th of May to the 5th of July, 24 hours a day. In Figure 2 the rainy days, amount of rain temperature, relative air humidity and the spore content in the air are given. Apple scab spores were discharged for the first time 13. 5. In the air the first spores were detected 20.5. The last spores were discharged from the leaves 22. 6., in the air spores were seen until the 4th of July. The maximum rate of apple scab spores in 1956 was $340 \mathrm{spores} / \mathrm{m}^{3}$. In 1957 the first spores were discharged 18. 5., the last ones 16. 7. In the air spores were detected from 18. 5. to 6. 7. (Fig. 3). During the primary infection period apple scab spores seem to be prevalent in the air every rainy day and, in addition, $2-3$ days following a heavy rain. In 1957 , thus, rain beginning the 10th of June at 4 o'clock and ending the 11th of June at 9 o'clock, produced only a slight spore content (Fig. 5), the rate of Venturia spores reaching, however, its maximum within 7 hours after the rain had stopped. 2850 spores $/ \mathrm{m}^{3}$ were, then, counted. The last spores in the air were identified 32 hours later. Venturia inaequalis ascospores are prevalent in the air mainly during daylight, this fungus belonging to the 'day spore group' described by GREGoRy (3).

A timing of sprays is being applied in most of the fruit growing areas in Finland in order to control apple scab. The beginning of the primary infection period and the end of it is being determined by the 'scab observers' in accordance with the first and last discharge of spores from the overwintered apple leaves (7). It is assumed that differences between the data on ascospore discharge and the spore content in the air may not cause trouble in the timing of sprays, since the number of spores at the beginning and at the end of the primary infection period is small. In addition, spores probably carried over by the wind from rainy areas do not cause infection in an orchard where the apple leaves are dry.

The content of Alternaria spores in the air does not seem to be influenced by rain or other weather conditions. Fusarium spores, on the other hand, were most abundant on rainy and warm days. High temperature seems to promote the spread of Fusarium spores more than that of Alternaria and Venturia spores (Fig. 2 and 3). 